\author{
Ewa Skowronek \\ Teresa Brzezińska-Wójcik \\ Andrzej Świeca \\ Marta J. Jóźwik \\ Maria Curie-Skłodowska University in Lublin \\ Faculty of Earth Science and Spatial Management \\ Department of Regional Geography and Tourism, \\ ewa.skowronek@poczta.umcs.lublin.pl; tbrzezin@poczta.umcs.lublin.pl; \\ andrzej.swieca@poczta.umcs.lublin.pl; marjoz@poczta.umcs.lublin.pl
}

\title{
ACADEMIC RESEARCH ACHIEVEMENTS IN THE GEOGRAPHY OF TOURISM AT THE DEPARTMENT OF REGIONAL GEOGRAPHY AND TOURISM, MARIA CURIE-SKŁODOWSKA UNIVERSITY, LUBLIN: DIDACTIC AND PRACTICAL APPLICATIONS
}

\begin{abstract}
The present paper is an attempt to assess academic research achievements in the field of the geography of tourism and their didactic and practical applications. The study method was a review of academic articles and archival compilations as well as materials collected in the department.
\end{abstract}

Keywords: tourism, tourism geography, educational offer, academic research, Maria Curie-Skłodowska University, Lublin.

\section{INTRODUCTION}

The traditions of education in the field of tourism geography at the Department of Regional Geography and Tourism, Maria Curie-Skłodowska University (UMCS) are fairly new. It was only in 2003 that the first steps to address the expectations of geography students were taken and a curriculum for the new specialisation was developed, giving rise to tourism geography. Its growing popularity led to a totally new degree being established, namely Tourism and Recreation. It was first opened in the academic year 2008/09.

As the educational offer on the Tourism and Recreation degree expanded, the department staff actively joined nationwide research trends in the field of tourism geography. Initially, the research covered basic questions on the growth determinants of tourism in the Lublin region. Subjects evolved with time, and attempts were made to assess the attractiveness of particular spatial units, research the development opportunities of various tourism forms and analyse the tourism function of selected areas. The new issues which have emerged recently include users' perception of tourism areas, the evaluation of the tourism potential of selected places, assessment of growth determinants of tourism offers and products, assessment of community attitudes towards the development of tourism, and the concept of 'tourism landscape'. These themes may be summarised as attempts to designate tourism regions. Research was also undertaken in cooperation with the tourism industry, which allowed in many cases the industry to take advantage of tourism opportunities.

This paper summarises the previous educational and research achievements of the Department in the field of tourism geography as well as their practical applications.

\section{RESEARCH METHODOLOGY AND DATA SOURCES}

The scope of the issues is both complex and heterogeneous, and encompasses the almost twenty-yearlong operation of the Department of Regional Geography and Tourism at UMCS. Historical research was employed in this paper in order to highlight the 
relatively dynamic changes that didactic and research activity has undergone throughout this period (McIntosh \& Goeldner 1984, after ALEJZIAK 2003). It was used to study the origins of research into tourism, analyse its educational offer, and find correlations between research and teaching activities. It also includes a compilation of applied activities related to tourism. For this purpose, the author used the methods of survey, typology, and mapping.

The analyses were based on original sources, namely the materials collected in the archive of the UMCS Department of Regional Geography and Tourism. Secondary sources were also utilised, including staff publications pertaining to tourism and analyses of academic and educational achievements (ŚWIECA \& BRZEZIŃSKA-WÓJCIK 2010, 2013a, b, ŚWIECA et al. 2012, BRZEZIŃSKA-WÓJCIK et al. 2015). A comprehensive review of the accomplishments of the departmental staff is contained in a monograph entitled From Geographic Region to Tourism Area [Od regionu geograficznego do regionu turystycznego] (2016).

\section{EDUCATION IN THE FIELD OF TOURISM GEOGRAPHY}

Research on tourism in the wider sense started as the discipline of tourism geography was launched in the department (Fig. 1). Since 2003, the educational offer has comprised the following subjects: History, Subject and Scope of Tourism Geography; Research Methods in Tourism Geography; Tourism Geography in Poland involving Sightseeing; Tourism Product: basics of Discovery and Creation; Tourism Regions of the World; as well as specialisation subject seminars and tutorials, Master's thesis workshops and practice.

The curriculum was enhanced with optional classes, such as Selected Aspects of Ethnography, The Tourism Value of the Lublin Region, Regional Differentiation of Tourism Attractiveness on Mediterranean Islands, Differentiation of the Natural and Cultural Heritage of the Lublin Region, and Tourism and Recreation Infrastructure. These were the issues covered before the Tourism and Recreation degree was established.

With the launch of the degree in Tourism and Recreation in 2008 (Fig. 1), the issues addressed by department staff underwent significant changes. The educational offer of the UMCS Institute of the Earth Sciences was thus greatly upgraded and the degree course is still taught at the university.

The mandatory classes at undergraduate level taught by departmental staff in the first period (2008 to 2012) included Basics of Tourism; Basics of Recreation, Historical Tourism; Regional Geography of the World; Tourism Geography; Methods in Tourism Services; Hotel
Industry; Tourism Trade Fairs and Field Practice. 2012 was marked by the new law on higher education which led to modifications to the curriculum. From that time on, staff on the first-cycle programme have led the following compulsory modules, i.e. large subject areas: Basics of Tourism and Recreation; Tourism Geography; Physical Culture; Economic and Legal Basics of Tourism and Leisure Activities; Tourism and Recreation Infrastructure; Tourism Trade Fairs; and Field Practice (BRZEZIŃSKA-WÓJCIK et al. 2016).

The educational offer of the department programme at the Master's degree level in 2008-12 comprised the following mandatory classes: Tourism Regions of Poland; Tourism Regions of the world; Research Methods in Tourism and Recreation; International Cooperation in Tourism and Recreation; Tourism Products; International Tourism Services; Marketing of Tourism and Recreation Services and a seminar on the Place and Role of Tourism and Recreation in the World Economy as well as Master's thesis tutorials and workshops. After the changes introduced in 2012, it has expanded to include the following mandatory modules: Tourism Policy and Economy; Product, Management and Marketing in Tourism and Recreation; Leisure, Health and Recreation; Research Methods and Techniques in Tourism and Recreation; Potential and Functional Tourism Regions (BRZEZIŃSKA-WÓJCIK et al. 2016).

From the very beginning of the degree, the team of department staff has supervised Bachelor candidates. Throughout the entire period considered, regardless of the changes in the curriculum, undergraduate students have attended classes within two specialisations: Organisation and Operation of Tourism Services and Physical and Wellness Recreation (Fig. 1).

In 2008-12, the first specialisation included the following subjects: Tourism of those with Disabilities; Organization and Activities of Travel Agencies; Office Work Organization. Since 2012 the modules have been: Organization and Activities of Travel Agencies; Tourism Services; Tourism Support.

The Physical and Wellness Recreation specialisation offered the following subjects in 2008-12: Psychophysiological basics of physical activity and Summer Camp. After the curriculum changes, the subject modules are as follows: Biomedical and Psycho-physical Basics of Recreation; Recreation Programme and Organization; Theoretical and Methodological Basics of Recreational Swimming with Elements of Water Rescue; Summer Recreation Camps; Winter Recreation Camps; Leisure Games.

Before the changes, i.e. in 2008-12, students were able to choose a third specialisation, Regional Tourism Economy: Tourism and Recreation Infrastructure; Tourism and Recreational Areas in the Lublin and Neighbouring Regions; Marketing of Local Tourism Resources; and Complementary Services in Tourism and Recreation. This was replaced with a new one in 2012, namely Manage- 


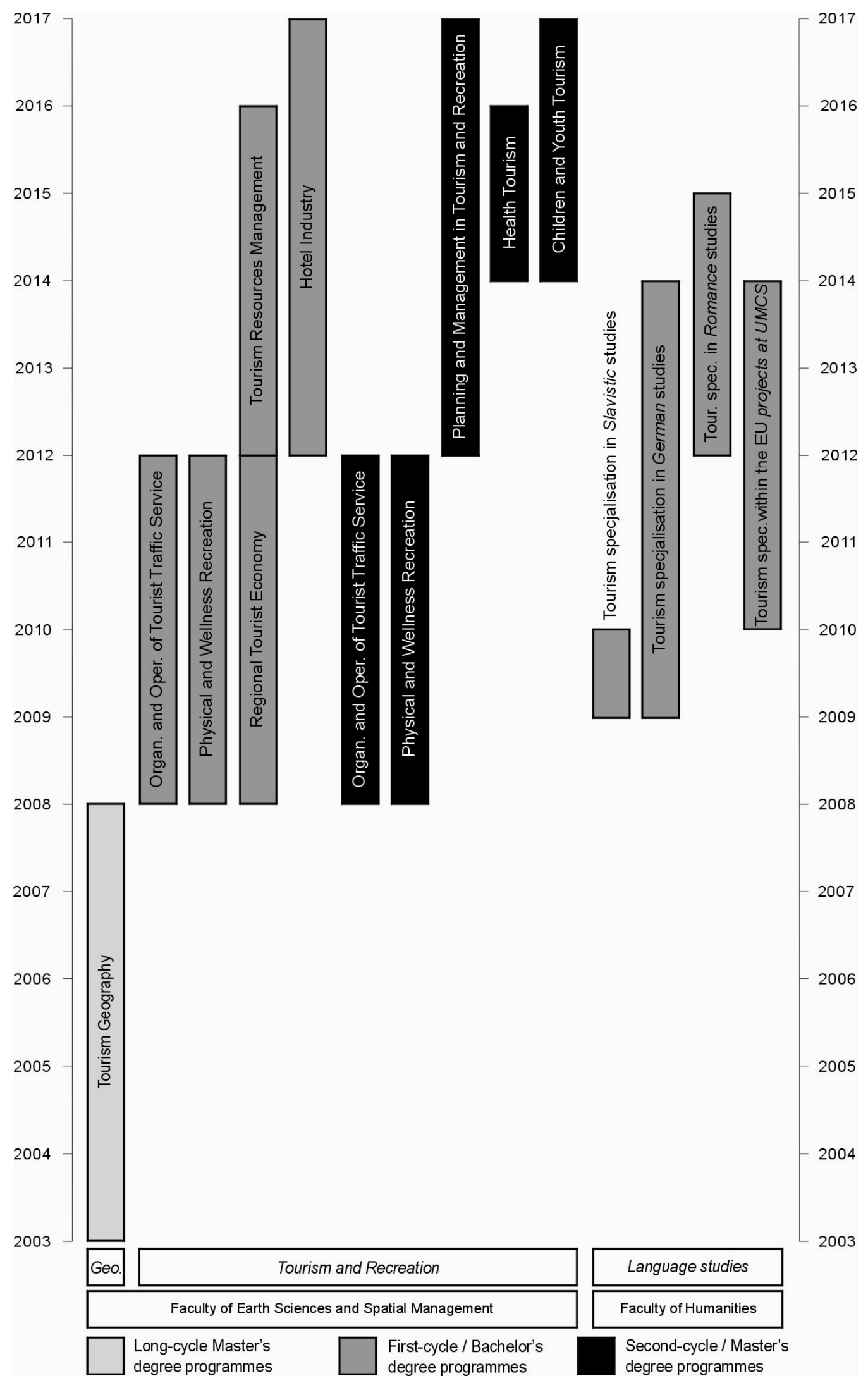

Fig. 1. Educational activities of departmental staff in respect of tourism geography Source: authors 
ment of Tourism Resources. The classes within this specialisation are co-lectured by department staff within the Analysis and Functioning of the Tourism Market subject module (Fig. 1). The introduction of a brand new specialisation devoted to the Hotel Industry also occurred in 2012 within which the staff participate in teaching the following modules: Hotel Market in Poland and Worldwide; Basic and Complementary Services in the Hotel Industry; Hotel Business Organization; Basics of Nutrition; Tasks and Techniques of Hotel Gastronomy; Hotel IT Systems; Hotel Business Management; Hotel Marketing.

Throughout the entire period during which the specialisations operated, department staff have supervised B.A. candidates during Bachelor's thesis tutorials and workshops. Over 70 Bachelor's theses were prepared within all three specialisations.

Until 2012, the second-cycle programme comprised the following specialisations: Organisation and Operation of Tourism Services and Physical and Wellness Recreation, with such classes as Physical Activity Medicine, Leisure Games, and Master's thesis tutorials and workshops. Students were also offered an optional subject, namely Human Nutrition. After the changes to the curriculum in 2012, students attend a Master's thesis preparation class within the specialisation they have selected: Planning and Management in Tourism and Recreation; Health Tourism or Children and Youth Tourism.

From the moment Tourism and Recreation was launched as a university degree, until 2016, over 100 theses were written.

Due to a growing interest in the degree, new tourism specialisations were launched at the Faculty of Humanities. Departmental staff have lectured students on such degrees as Slavic studies (Tourism Geography of Poland and the World) [2009-10]; German studies (Basics of Tourism, Basics of Recreation, Regional Geography of Poland, Basics of Tourism and Recreation, Regional Geography of the World, Tourism Geography of Europe, Sightseeing, Tourism Geography of Poland with Elements of Sightseeing, Hotel Industry, Tourism Geography of NonEuropean Countries, Field Practice and Tourism Trade Fairs) [2009-14]; Romance Studies (Basics of Tourism, Tourism Infrastructure, Regional Geography of the World, Tourism Geography of Poland with Elements of Sightseeing, Hotel Industry) [2012-15] (BRZEZIŃSKA-WÓJCIK et al. 2016).

\section{RESEARCH ACTIVITIES IN RESPECT OF TOURISM GEOGRAPHY}

The research subjects conducted by departmental staff have evolved over time along with changing needs in terms of both education and their own development.
Initially, the focus was placed mainly on factors determining the development of tourism in selected administrative units, geographical sub-regions, and protected areas (BRZEZIŃSKA-WÓJCIK et al., eds. 2016). Simultaneously, the researchers analysed changes to the geographical environment of the Lublin region induced by tourism and recreation (e.g. KRUKOWSKA et al. 2003, ŚWIECA et al. 2007). Attempts were also made to assess the geographical environment in respect of tourism (e.g. TUCKI 2003, TUCKI \& ŚWIECA 2013) and to analyse the importance of tourism values (KRUKOWSKA \& SKOWRONEK 2009) (Fig. 2).

Since 2006, numerous dissertations have been published which pertain to the issue of possible development of various tourism forms, including active tourism (ŚWIECA 2006), cultural tourism (e.g. KRUKOWSKA 2009a), geotourism (BRZEZIŃSKA-WÓJCIK 2010), nature tourism (BRZEZIŃSKA-WÓJCIK \& ŚWIECA 2014), social tourism (e.g. TUCKI \& SKOWRONEK 2012, SHAW et al. 2017) and health tourism (e.g. TUCKI \& CLEAVE 2014).

Another area of research encompassed an assessment of the activity of authorities, organisations, and local communities of the Lublin region in the field of tourism (e.g. TUCKI 2007, SKOWRONEK 2015).

In 2008, the scope of research was expanded to include user perception of tourism areas with the examples of Lublin (e.g. SKOWRONEK et al. 2008) and the Łęczna-Włodawa Lake District (KRUKOWSKA \& ŚWIECA 2012). At the same time, research was launched on the tourism development of selected sub-regions of the wider Lublin region (e.g., KRUKOWSKA \& ŚWIECA 2008, TUCKI et al. 2012, ŚWIECA et al. 2015).

Within the research the knowledge of tourism resources and methods used in tourism geography gave rise to a new trend pertaining to tourism potential and function. The results of research on the former with respect to the Lublin region were presented through examples from the voivodship, selected communes, and protected areas (e.g. BRZEZIŃSKA-WÓJCIK \& SKOWRONEK 2009, BRZEZIŃSKA-WÓJCIK \& ŚWIECA 2011). The development of the tourism function was described in respect of selected sub-regions and cities (e.g. KRUKOWSKA 2009b, ŚWIECA \& BRZEZIŃSKA-WÓJCIK 2011, BRZEZIŃSKA-WÓJCIK et al. 2017).

The growth determinants of tourism offer and creation of tourism products formed another direction (e.g. KRUKOWSKA 2011, SKOWRONEK 2011, BRZEZIŃSKAWÓJCIK et al., ed. 2016 and literature cited therein).

The first papers containing the results of research on the quality assessment of the tourism area and landscape, including its definition and perception, were published in 2013 (e.g. TUCKI \& VARGAS-SANCHES 2013, SKOWRONEK et al. 2013). 


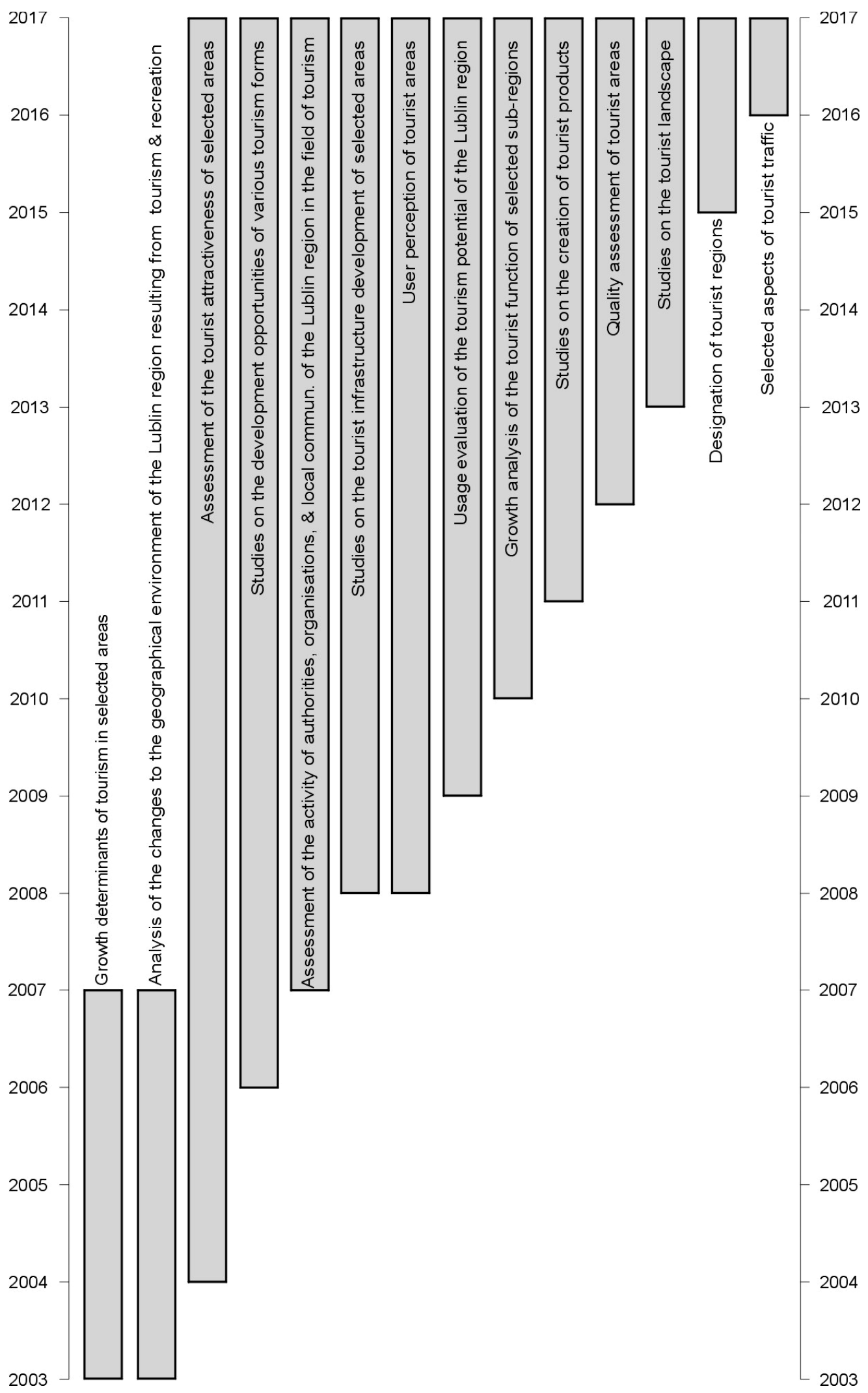

Fig. 2. Research activities of departmental staff in respect of tourism geography Source: authors 
In the last two years, the staff have attempted to tackle issues which are important and difficult methodology-wise. The first concerns selected aspects of tourism (e.g. KRUKOWSKA et al. 2016), while the other constitutes a comprehensive tourism regionalisation of the Roztocze region (BRZEZIŃSKA-WÓJCIK et al. 2016, BRZEZIŃSKA-WÓJCIK et al. 2017). It should be noted, however, that earlier studies had already presented a designation of tourism regions on the basis of tourism potential (TUCKI 2009) or the development stage of the tourism function (KRUKOWSKA 2009b).

In terms of areas analysed, research into tourism geography has focused primarily on the Lublin voivodship.

\section{RESEARCH ACCOMPLISHMENTS IN THE DEPARTMENT IN THE FIELD OF TOURISM GEOGRAPHY AS APPLIED IN TEACHING AND PRACTICE}

\subsection{TEACHING PROJECTS AND GRANTS IN RESPECT OF TOURISM}

As their competences in the field of tourism geography expanded, departmental staff looked for practical applications on the market of the knowledge they imparted. They involved themselves in the process of acquiring funds for educational purposes resulting in obtaining and implementing three teaching grants in 2010-16. All these projects were aimed at reinforcing the position and the competitiveness of students on the labour market.

Table 1. Educational grants in respect of tourism obtained and implemented by the department

\begin{tabular}{|c|c|c|c|}
\hline \multicolumn{4}{|c|}{ Teaching grants obtained in respect of tourism } \\
\hline Years & Project name and number/symbol & Project objective & Financing source \\
\hline 2010-2015 & $\begin{array}{l}\text { UMCS for Labour Market and Knowledge-Based } \\
\text { Economy - grant No. 04.01.01-00-362/10 within } \\
\text { the Human Resources Development Operational } \\
\text { Programme }\end{array}$ & $\begin{array}{l}\text { Launch of a specialisation } \\
\text { available for UMCS } \\
\text { students: Organisation and } \\
\text { functioning of tourism in the } \\
\text { region }\end{array}$ & $\begin{array}{l}\text { European Union funds } \\
\text { provided under the } \\
\text { European Social Fund }\end{array}$ \\
\hline 2012-2014 & $\begin{array}{l}\text { Challenges in Hospitality and Tourism Education/ } \\
\text { LDV/2012/PP/ANK/0009 - grant No. 2012-1-PL1- } \\
\text { LEO04-281211 under the Lifelong Learning } \\
\text { Program, the LEONARDO DA VINCI sub- } \\
\text { programme, and the Leonardo da Vinci Partnership } \\
\text { Projects Action }\end{array}$ & $\begin{array}{l}\text { Development of vocational } \\
\text { education through the } \\
\text { exchange of research staff } \\
\text { and students (internships } \\
\text { abroad) }\end{array}$ & European Union funds \\
\hline Since 2016 & $\begin{array}{l}\text { Geo4work - development of professional competences of } \\
\text { the students of the Institute of Earth Sciences and } \\
\text { Spatial Economy at UMCS and reinforcement of their } \\
\text { competitiveness in the modern labour market - } \\
\text { competition No. 1/PRK/POWER/3.1/2015, under } \\
\text { the Knowledge Education Development Operational } \\
\text { Programme 2014-2020 }\end{array}$ & $\begin{array}{l}\text { Reinforcement of } \\
\text { professional and } \\
\text { communication skills of the } \\
\text { UMCS students at the } \\
\text { Institute of Earth Sciences } \\
\text { and Spatial Economy and } \\
\text { their competitiveness on the } \\
\text { labour market }\end{array}$ & $\begin{array}{l}\text { The National Centre } \\
\text { for Research and } \\
\text { Development }\end{array}$ \\
\hline \multicolumn{4}{|c|}{ Participation in teaching projects and grants in respect of tourism } \\
\hline Years & Project name and number/symbol & Project objective & Financing source \\
\hline 2000 & $\begin{array}{l}\text { The Lublin Region - natural and cultural heritage - } \\
\text { grant No. 41-G/2000 }\end{array}$ & Conducting classes & $\begin{array}{l}\text { State budget } \\
\text { and the European } \\
\text { Social Fund }\end{array}$ \\
\hline 2010-2012 & $\begin{array}{l}\text { On the career path. Preparation for work in the tourism } \\
\text { industry - a project implemented by the Lublin } \\
\text { Regional Tourism Organisation under the Human } \\
\text { Capital Operational Programme, Priority VI: Labour } \\
\text { market for all. Measure 6.1: Improving access to } \\
\text { employment and promotion of professional } \\
\text { activities in the region, Sub-measure 6.1.1: Support } \\
\text { for the unemployed in the regional labour market }\end{array}$ & Conducting classes & $\begin{array}{l}\text { Co-financed by the } \\
\text { European Social Fund }\end{array}$ \\
\hline
\end{tabular}

Source: compiled from T. BRZEZIŃSKA-WÓJCIk et al. (2016). 
Table 2. Applied activities of departmental staff in respect of tourism geography

\begin{tabular}{|c|c|c|c|c|}
\hline Years & $\begin{array}{c}\text { Project names and source } \\
\text { of financing/actions }\end{array}$ & Purpose of cooperation & Customer & Effects \\
\hline $2003-2007$ & $\begin{array}{l}\text { Creating the Lublin Brand by the City of } \\
\text { Lublin }\end{array}$ & $\begin{array}{l}\text { Analysis of residents' and } \\
\text { tourists' perception of Lublin }\end{array}$ & $\begin{array}{l}\text { Mayor of Lublin } \\
\text { and the City } \\
\text { Promotion Office }\end{array}$ & $\begin{array}{l}\text { Study report used in } \\
\text { strategy documentation }\end{array}$ \\
\hline $2006-2007$ & $\begin{array}{l}\text { Central Cycling Route: Roztocze Krasnik-Lviv } \\
\text { by the Marshal of the Lublin Voivodship } \\
\text { within the scope of the Neighbourhood } \\
\text { Programme of Poland - Belarus - Ukraine } \\
\text { INTERREG III A/TACIS CBC }\end{array}$ & $\begin{array}{l}\text { Promotion of a cycling route } \\
\text { by the academic community }\end{array}$ & $\begin{array}{l}\text { Marshal of the } \\
\text { Lublin } \\
\text { Voivodship }\end{array}$ & $\begin{array}{l}\text { National academic } \\
\text { conference, involvement } \\
\text { in the preparation of } \\
\text { monograph }\end{array}$ \\
\hline $2006-2010$ & $\begin{array}{l}\text { Study of conditions and an analysis of the access- } \\
\text { ibility of Roztocze National Park for tourism and } \\
\text { education, as well as an assessment of its impact } \\
\text { on the natural and social environment }\end{array}$ & $\begin{array}{l}\text { Tourism monitoring } \\
\text { in the Roztocze National Park }\end{array}$ & $\begin{array}{l}\text { Directorate of } \\
\text { the Roztocze } \\
\text { National Park } \\
(\mathrm{RPN})\end{array}$ & Academic publications \\
\hline $2013-2015$ & $\begin{array}{l}\text { Discovering and promoting the biodiversity of } \\
\text { Roztocze as a border region of natural and } \\
\text { cultural heritage within the Financial } \\
\text { Mechanism of the European Economic Area } \\
\text { 2009-2014, Operational Programme }\end{array}$ & $\begin{array}{l}\text { Substantive content preparation } \\
\text { of the monograph chapters } \\
\text { pertaining to the natural and } \\
\text { cultural heritage, as well as } \\
\text { tourism }\end{array}$ & $\begin{array}{l}\text { Directorate } \\
\text { of Roztocze } \\
\text { National Park } \\
\text { (RPN) }\end{array}$ & $\begin{array}{l}\text { Field trips, involvement } \\
\text { in the preparation of } \\
\text { monograph }\end{array}$ \\
\hline 2011 & $\begin{array}{l}\text { Science }<=>\text { Business under the National } \\
\text { Cohesion Strategy Human Capital } \\
\text { Programme }\end{array}$ & \begin{tabular}{|l|} 
Analysis of the cooperation \\
between entities operating \\
in the Land of the Loess Ravines \\
Local Tourism Organisation for \\
the creation of tourist offer
\end{tabular} & $\begin{array}{l}\text { Association for } \\
\text { socio-economic } \\
\text { development, } \\
\text { CIVIS in Chełm }\end{array}$ & $\begin{array}{l}\text { Field trips, } \\
\text { academic } \\
\text { publications }\end{array}$ \\
\hline 2012 & $\begin{array}{l}\text { Science for Economy under the National } \\
\text { Cohesion Strategy Human Capital } \\
\text { Programme }\end{array}$ & $\begin{array}{l}\text { Offer analysis in respect of } \\
\text { cultural, wildlife and active } \\
\text { tourism in the Lublin voivod- } \\
\text { ship }\end{array}$ & $\begin{array}{l}\text { Association of } \\
\text { socio-economic } \\
\text { development } \\
\text { CIVIS in Chełm }\end{array}$ & $\begin{array}{l}\text { Academic } \\
\text { publications }\end{array}$ \\
\hline 2013 & $\begin{array}{l}\text { Examination of tourism flows in the Lublin } \\
\text { voivodship }\end{array}$ & $\begin{array}{l}\text { Preparation of research } \\
\text { methods and tools }\end{array}$ & $\begin{array}{l}\text { Lublin Regional } \\
\text { Tourism } \\
\text { Organization } \\
\end{array}$ & $\begin{array}{l}\text { Tools employed in } \\
\text { the studies performed }\end{array}$ \\
\hline 2013-2015 & $\begin{array}{l}\text { 'Roztocze' Cross-border Biosphere Reserve } \\
\text { under the National Fund for Environmental } \\
\text { Protection and Water Management }\end{array}$ & $\begin{array}{l}\text { Preparation of documentation } \\
\text { accompanying the motion to } \\
\text { create the 'Roztocze' Cross- } \\
\text { border Biosphere Reserve }\end{array}$ & $\begin{array}{l}\text { Directorate of } \\
\text { the Roztocze } \\
\text { National Park } \\
(\mathrm{RPN})\end{array}$ & $\begin{array}{l}\text { Co-authorship of } \\
\text { monograph }\end{array}$ \\
\hline 2013-2016 & $\begin{array}{l}\text { Tourism, Wellbeing and Ecosystem Services } \\
\text { (TObeWELL) under the European Program } \\
\text { for Cooperation in the field of Academic and } \\
\text { Technical Research }\end{array}$ & $\begin{array}{l}\text { Studies on the quality } \\
\text { of life in respect of tourism } \\
\text { development }\end{array}$ & $\begin{array}{l}\text { ISCH COST } \\
\text { Action IS } 1204 \\
\text { international } \\
\text { project }\end{array}$ & Chapter in monograph \\
\hline 2016 & $\begin{array}{l}\text { The analysis and evaluation of the barriers faced } \\
\text { by local authorities in tourism promotion }\end{array}$ & $\begin{array}{l}\text { Preparation of } \\
\text { recommendations }\end{array}$ & City of Lublin & $\begin{array}{l}\text { Academic conference, } \\
\text { recommendations } \\
\text { implemented in the } \\
\text { document prepared for } \\
\text { the Ministry of Sport and } \\
\text { Tourism and the Polish } \\
\text { Tourism Organisation } \\
\end{array}$ \\
\hline
\end{tabular}

Source: authors.

The staff were are also involved in projects of the local tourism industry contracted to be responsible for carrying out training courses (Fig. 1, Table 1).

It should be added that a team of staff have been actively involved in the development and the educational needs of the Institute of the Earth Sciences and Spatial Economy by means of supervising degree curricula and promoting the degree of Tourism Geography in Poland and abroad.

\subsection{APPLICATION OF RESEARCH IN RESPECT OF TOURISM GEOGRAPHY}

The application of academic and research accomplishments is essential in the department's activity (BRZEZIŃSKA-WÓJCIK et al. 2016). Expert reports and product ideas prepared at a customer's request have proved useful and valuable. The reports have concerned development conditions for tourism and recreation functions (HARASIMIUK et al. 2007), the evaluation of 
the tourism potential in the Lublin region (ŚWIECA 2015), and the analysis of development opportunities for health tourism in the Lublin voivodship (TUCKI \& HADZIK 2013). The latter, i.e. the product ideas, were related to the geotourism trail and the Kamienny Las Geopark in the Roztocze region (BRZEZIŃSKA-WÓJCIK et al. 2011, KRĄIEC et al. 2011).

Furthermore, staff participate in projects and activities related to the development of tourism in the Lublin region (Table 2).

One of the tangible results of these projects is cooperation with the bodies responsible for the development of tourism in the voivodship and with the local tourism industry in the form of materials and recommendations used in the strategy documentation, as well as publications aimed at promoting information about the region (e.g. GRABOWSKI et al., ed. 2015). Common academic publications (e.g. SKOWRONEK et al. 2015) and experience exchange during academic and academic-industrial conferences (e.g. Local and regional tourism development determinants in Nałęczow; BRZEZIŃSKA-WÓJCIK et al. 2016) may also be considered as significant positive effects.

Furthermore, the staff (T. Brzezińska-Wójcik, R. Krukowska \& E. Skowronek) act as experts at the office of the Marshal of the Lublin voivodship (under the Regional Operational Programme of the Lublin Voivodship in 2014-20) in the areas of nature tourism and natural heritage.

\section{SUMMARY}

This paper is an attempt to assess the academic and research accomplishments of the staff of the Department of Regional and Tourism Geography at UMCS in respect of tourism geography. It shows that the Lublin academic centre has undergone a major development in respect of this research direction in a relatively short time.

In the field of education, recent years have seen the preparation and improvement of degree curricula, as well as the assurance of an appropriately high quality of teaching. Following the education reform, the department's objectives and the needs of the labour market, its offer has been adjusted appropriately and optimised in respect of practical application. Cooperation has been established with the tourism industry with regard to changes in the curriculum, the launch of a practical specialisation, and entrusting practical experts with certain subjects and issues. The scope and the attractiveness of professional practice have been increased. In response to expectations regarding useful solutions for the tourism sector and local authorities, and appropriate theses have been prepared. All these steps taken have proved relevant for students, as indicated by the constantly high and persistent interest in the Tourism and Recreation degree among university candidates.

There has been a considerable evolution in the field of research in the department from the basic characteristics of tourism areas, analysis and evaluation of the development opportunities of various tourism forms, through the assessment of tourism potential and function, as well as area quality, to the issue of tourism regionalisation. Results obtained are acknowledged by the academic community both in national and foreign academic centres, which may be seen from the results being published in renowned journals, and with the participation of foreign writers. The practical aspect of research is also of importance, as the department staff have been involved in projects related to tourism development in the region of Lublin, preparing materials included in strategy documentation, and acting in the role of experts in the matters of tourism.

To maintain the popularity of educational activities in the changing socio-economic and geopolitical realities of the future poses a great challenge. The place and role of tourism geography will depend largely on the capacity and responsiveness of the labour market, which in turn produces specific expectations in respect of education. The internationalisation of university teaching is an important factor which should be taken into account.

It will also be imperative to identify new research trends in tourism geography, especially in the field of quality and the identity of tourism and leisure areas, as well as their sustainable use. Issues that require further study include definition of concepts, expanding and refining methodological workshop, as well as raising awareness of tourism phenomena presented from a spatial perspective. Nevertheless, the vital aspect of any research undertaken is its practical applicability.

Translated by Konrad Dejko

\section{BIBLIOGRAPHY}

ALEJZIAK W., 2003, Perspektywy i kierunki badań naukowych nad turystyką, [in:] G. Gołembski (ed.), Kierunki rozwoju badań naukowych w turystyce, Wyd. Nauk. PWN, Warszawa, pp. 231-248.

BRZEZIŃSKA-WÓJCIK T., 2010, Koryta rzek z progami skalnymi jako ważne obiekty dydaktyczne w geoturystyce strefy krawędziowej Roztocza, Zeszyty Naukowe Wyższej Szkoty Spoteczno-Przyrodniczej im. Wincentego Pola w Lublinie, 9, pp. 153172.

BRZEZIŃSKA-WÓJCIK T., SKOWRONEK E., 2009, Potencjał turystyczny Roztocza Tomaszowskiego na przykładzie gminy 
miejsko-wiejskiej Krasnobród, Annales UMCS, B, 64, 1, doi: 10.2478/v10066-008-0027-4, pp. 171-199.

BRZEZIŃSKA-WÓJCIK T., SKOWRONEK E., 2017, Potencjalne i funkcjonalne obszary turystyczne na Roztoczu w świetle wyników wielowymiarowej analizy porównawczej - wyzwania i problemy metodyczne, Prace Geograficzne Instytutu Geografii $i$ Gospodarki Przestrzennej UJ, in press.

BRZEZIŃSKA-WÓJCIK T., ŚWIECA A., 2011, Potencjał turystyczny Wyniosłości Giełczewskiej (środkowowschodnia Polska), Polish Journal of Sport and Tourism, 18, pp. 244-255.

BRZEZIŃSKA-WÓJCIK T., ŚWIECA A., 2014, Stan i perspektywy edukacyjnej turystyki przyrodniczej na Roztoczu w kontekście strategii aktywnego uczestnictwa, Barometr Regionalny, 12 (4), pp. 123-132.

BRZEZIŃSKA-WÓJCIK T., JÓŹWIK M.J., ŚWIECA A., 2015, Geografia turyzmu oraz turystyka i rekreacja w lubelskim ośrodku geograficznym, Turystyka $i$ Rekreacja - Studia i Prace, 14: Uwarunkowania i plany rozwoju turystyki, 14, pp. 75-89.

BRZEZIŃSKA-WÓJCIK T., SKOWRONEK E., ŚWIECA A. (eds.), 2016, Od regionu geograficznego do regionu turystycznego. Lubelszczyzna - implikacje historyczne, teoretyczne, naukowo-badawcze, edukacyjne, Wyd. UMCS, Lublin, ss. 195.

BRZEZIŃSKA-WÓJCIK T., SKOWRONEK E., ŚWIECA A., 2017, Diversity of the tourism potential and functions in the Roztocze region, Ekonomiczne Problemy Turystyki, in press.

BRZEZIŃSKA-WÓJCIK T., ŚWIECA A., TUCKI A., 2009, Możliwości rozwoju turystyki w województwach wschodniej Polski, Polish Journal of Sport and Tourism, 16(2), pp. 65-84.

BRZEZIŃSKA-WÓJCIK T., GRABOWSKI T., MOSKAL A., PAWŁOWSKI A., WIECHOWSKA I., 2011, Szlak geoturystyczny Roztocza Środkowego. Informator - mapa turystyczna 1 : 50 000, Wyd. Kartpol, Lublin.

BRZEZIŃSKA-WÓJCIK T., JÓŹWIK M.J., SKOWRONEK E., ŚWIECA A., 2016, Ewolucja problematyki naukowo-badawczej oraz działalności dydaktycznej w Zakładzie Geografii Regionalnej (i Turyzmu) UMCS w latach 1956-2016, [in:] T. BrzezińskaWójcik, E. Skowronek, A. Świeca (eds.), Od regionu geograficznego do regionu turystycznego. Lubelszczyzna - implikacje historyczne, teoretyczne, naukowo-badawcze, edukacyjne, Wyd. UMCS, Lublin, pp. 38-88.

GRABOWSKI T., HARASIMIUK M., KASZEWSKI B.M., KRAVCHUK Y., LORENS B., MiCHALCZYK Z., SHABLIY O. (ed.), 2015, Roztocze - przyroda $i$ człowiek, Wyd. Roztoczańskiego Parku Narodowego, Zwierzyniec, ss. 527.

HARASIMIUK M., ŚWIECA A., KRUKOWSKA R., TUCKI A., 2007, Potencjały i uwarunkowania rozwoju funkcji turystycznych i rekreacyjnych w gminie Sosnowica, [in:] Opracowanie innowacyjnego planu rozwoju Gminy Sosnowica opartego na posiadanym potencjale i czynnym wykorzystaniu wiedzy, mps, Lublin.

KRĄPIEC M., JANKOWSKI L., MARGIELEWSKI W., BURACZYŃSKI J., KRĄPIEC P., URBAN J., WYSOCKA A., DANEK M., SZYCHOWSKA-KRAPIEC E., BOLKA M., BRZEZIŃSKA-WÓJCIK T., CHABUDZIŃSKI Ł., WAŚKOWSKA A., 2011, Geopark Kamienny Las na Roztoczu. Koncepcja geoochrony wraz z wykonaniem dokumentacji i badań naukowych niezbędnych dla funkcjonowania tej formy ochrony, Akademia Górniczo-Hutnicza im. Stanisława Staszica w Krakowie, Wydział Geologii, Geofizyki i Ochrony Środowiska, Kraków, typescript.

KRUKOWSKA R., 2009a, Walory kulturowe jako podstawa rozwoju turystyki we Włodawie, Polish Journal of Sport and Tourism, 16, 3, pp. 143-151.

KRUKOWSKA R., 2009b, Pojezierze Łęczyńsko-Włodawskie - funkcja turystyczna regionu, Folia Touristica, 21, pp. 165-184.

KRUKOWSKA R., 2011, Tworzenie sieciowych produktów turystycznych na przykładzie Sielskiej Krainy w Krainie Lessowych Wąwozów, [in:] Nauka<=>biznes. Zbiór raportów badaw- czych opracowanych przez pracowników naukowych i naukowodydaktycznych - przedstawicieli lubelskiego środowiska naukowego, Chełmskie Stowarzyszenie Rozwoju Społeczno-Gospodarczego CIVIS, Chełm, pp. 415-449.

KRUKOWSKA R., SKOWRONEK E., 2009, Walory przyrodnicze jako podstawa rozwoju turystyki $\mathrm{w}$ gminie Włodawa, Polish Journal of Sport and Tourism, 16, 1, pp. 15-22.

KRUKOWSKA R., ŚWIECA A., 2008, The development of second homes as a form of using recreational areas for tourist purposes as exemplified by the Łęczna-Włodawa Lake District, [in:] Conditions of the foreign tourism development in Central and Eastern Europe, ser. "Tourism in Geographical Environment", 10, Wrocław, pp. 175-184.

KRUKOWSKA R., ŚWIECA A., 2012, Tourism and recreation in the Łęczyńsko-Włodawskie Lake District (Middle-East Poland) survey results, Polish Journal of Natural Sciences, 27(4), pp. 393405.

KRUKOWSKA R., SKOWRONEK E., KRUKOWSKI M., 2003, Zmiany w krajobrazie gminy Włodawa zachodzące pod wpływem użytkowania rekreacyjnego, Problemy Ekologii Krajobrazu, 11, pp. 45-54.

KRUKOWSKA R., ŚWIECA A., TUCKI A., 2016, Kim jest turysta w parku narodowym? Wyniki badań ankietowych z Roztoczańskiego Parku Narodowego, [in:] R. Wiluś, J. Wojciechowska (eds.), Człowiek w turystyce - role, potrzeby, zachowania, ser. „Warsztaty z Geografii Turyzmu”, 7, Wyd. Uniwersytetu Łódzkiego, Łódź, pp. 129-140.

ShaW G., Cloquet I., CleAve P., TUCKI A., Custódio M.J.F., THEUMA A., 2017, A life-course analysis older tourists and their changing patterns of holiday behaviour, [in:] M.K. Smith, L. Puczkó (eds.), The Routledge handbook of health tourism, Routledge, London and New York, pp. 113-124, https:// www.routledgehandbooks.com/doi/10.4324/9781315693774. $\operatorname{ch} 3$.

SKOWRONEK E., 2011, Uwarunkowania rozwoju oferty turystycznej Krainy Lessowych Wąwozów na przykładzie produktu Kraina Zdrowia, [in:] Nauka $<=>$ biznes. Zbiór raportów badawczych opracowanych przez pracowników naukowych i naukowo-dydaktycznych - przedstawicieli lubelskiego środowiska naukowego, Chełmskie Stowarzyszenie Rozwoju Społeczno-Gospodarczego CIVIS, Chełm, pp. 62-92.

SKOWRONEK E., 2015, Klaster jako forma współpracy w turystyce, Europa Regionum, 24, pp. 129-140.

SKOWRONEK E., BRZEZIŃSKA-WÓJCIK T., KRUKOWSKA R., 2008, Przestrzeń turystyczna Lublina w ocenie mieszkańców, [in:] M. Dziekanowska, J. Styk (eds.), Region w koncepcjach teoretycznych i diagnozach empirycznych, Wyd. Perfekta info, Lublin, pp. 211-230.

SKOWRONEK E., JÓŹWIK M. J., TUCKI A., 2013, Krajobraz turystyczny - koncepcja teoretyczna, [in:] R. Wiluś, J. Wojciechowska (eds.), Nowe-stare formy turystyki w przestrzeni, ser. „Warsztaty z Geografii Turyzmu”, 3, pp. 63-77.

SKOWRONEK E., BRZEZIŃSKA-WÓJCIK T., HARASIMIUK M., RUTKOWSKI T., KAROLINA S., ŚWIECA A., CZERNIEC W., 2015, Projekt zintegrowanego produktu turystycznego Szlak zdrowia $i$ urody - spotkanie $z$ naturą $w$ świetle geograficznych uwarunkowań Obszaru Funkcjonalnego Powiśle, Europa Regionum, 23, pp. 119-136.

ŚwIECA A., 2015, Potencjat turystyczny regionu lubelskiego, www. kil.lubelskie.pl/wp-content/uploads/2013/08/Potencja\%C 5\%82-turystyczny-regionu-lubelskiego-Prof.-dr-hab.-And rzej-\%C5\%9Awieca.pdf; 10.08.2015.

ŚWIECA A., 2006, Aktywne formy wypoczynku - wyzwaniem współczesnego człowieka, [in:] A. Świeca, K Kałamucki. (eds.), Turystyka aktywna i jej rozwój na Roztoczu - regionie pogranicza, Kartpol s.c., Lublin, pp. 13-20. 
ŚWIECA A., BRZEZIŃSKA-WÓJCIK T., 2010, Nauka i dydaktyka $\mathrm{w}$ geografii turyzmu oraz $\mathrm{w}$ turystyce i rekreacji w lubelskim ośrodku geograficznym, [in:] S. Tanaś (ed.), Nauka i dydaktyka w turystyce i rekreacji, Łódzkie Towarzystwo Naukowe, Łódź, pp. 201-212.

ŚWIECA A., BRZEZIŃSKA-WÓJCIK T., 2011, Zróżnicowanie przestrzeni turystycznej miasta Lublina, [in:] B. Włodarczyk (ed.), Turystyka. Księga jubileuszowa w 70. rocznice urodzin Profesora Stanistawa Liszewskiego, Wyd. Uniwersytetu Łódzkiego, Łódź, pp. 231-244.

ŚWIECA A., BRZEZIŃSKA-WÓjCIK T., 2013a, Metodyczne i teoretyczne aspekty $\mathrm{w}$ badaniach nad turystyką $\mathrm{w}$ geograficznym ośrodku lubelskim, [in:] L. Butowski (ed.), Badania naukowe w turystyce - stan i perspektywy rozwoju, ser. Monografie, Instytut Turystyki, Warszawa, pp. 153-174.

ŚWIECA A., BRZEZIŃSKA-WÓJCIK T., 2013b, Przestrzeń turystyczno-rekreacyjna Lubelszczyzny $\mathrm{w}$ świetle dotychczasowych opracowań geograficznego ośrodka lubelskiego, [in:] Wspótczesne uwarunkowania i problemy rozwoju turystyki, R. Pawlusiński (ed.), IG iGP UJ, Kraków, pp. 315-328.

ŚWIECA A., KRUKOWSKA R., TUCKI A., 2007, Possibilities for the Development of Tourism in the Lublin Region, [in:] G. Godlewski, M. Bochenek (ed.), Tourism. Theory - Conditions - Experiences, Biała Podlaska, pp. 69-98.

ŚWIECA A., KRUKOWSKA R., TUCKI A., SKOWRONEK E., BRZEZIŃSKA-WÓJCIK T., KOCIUBA W., JÓŹWIK M., 2012, Possibilities of tourist use of natural and cultural resources in the Lublin region - case study, Annales UMCS, B, LXVII, 1, pp. $219-244$.

ŚWIECA A., BRZEZIŃSKA-WÓJCIK T., SKOWRONEK E., KRUKOWSKA R., TUCKI A., GRABOWSKI T., MALSKA M., ZINKO J., BRUSAK V., PANDIAK I., SHEVCHUK O., 2015, Turystyka na Rozto$c z u$, [in:] T. Grabowski, M. Harasimiuk, B.M. Kaszewski, Y. Kravchuk, B. Lorens, Z. Michalczyk, O. Shabliy (eds.), Roztocze - przyroda i człowiek, Wyd. Roztoczańskiego Parku Narodowego, Zwierzyniec, pp. 389-427.
TUCKI A., 2003, Próba oceny środowiska przyrodniczego dla potrzeb turystyki na przykładzie gmin powiatu Łęczyńskiego, Annales UMCS, B, LVIII, 6, pp. 139-155.

TUCKI A., 2007, Aktywność władz lokalnych gmin regionu lubelskiego w dziedzinie turystyki, [in:] M. Żabka, R. Kowalski (eds.), Przyroda a turystyka we wschodniej Polsce, Wyd. Akademii Podlaskiej, Siedlce, pp. 345-360.

TUCKI A., 2009, Propozycja regionalizacji turystycznej województwa lubelskiego, Folia Turistica, 21, pp. 145-164.

TUCKI A., ClEAVE P., 2014, Medical tourism - new growing industry on a concealed market, European Journal of Medical Technologies, 4(5), pp. 38-46.

TUCKI A., HADZIK A., 2013, Analiza możliwości rozwoju turystyki $z$ drowotnej w województwie lubelskim w kontekście zintensyfikowanej inteligentnej specjalizacji regionu $w$ dziedzinie ustug medycznych $i$ prozdrowotnych. Raport końcowy $z$ badania dziedzinowego, Prefekta info, Lublin.

TUCKI A., SKOWRONEK E., 2012, Analiza popytu na turystykę społeczną w Polsce na przykładzie projektu Europe Senior Tourism realizowanego w lubelskim biurze podróży, Prace Naukowe Uniwersytetu Ekonomicznego we Wrocławiu, 259, pp. 35-42.

TUCKI A., ŚWIECA A., 2013, Policy and tourism development as exemplified by the Lublin region (southeast Poland), Tourism Review International, 17(2), pp. 131-135.

TUCKI A., VARGAS-SANCHES A., 2013, Residents attitude to tourism and their quality of life, [in:] Linking wellness tourism to ecosystem services: towards a research agenda. Book of abstracts, COST Action TObeWELL, First Seminar Wageningen, Netherlands 3-5 September 2013, Wageningen.

TUCKI A., SKOWRONEK E., KRUKOWSKA R., 2012, Wielkość i zróżnicowanie bazy noclegowej jako determinanta popytu turystycznego w regionie lubelskim, Zeszyty Naukowe Uniwersytetu Szczecińskiego, 699, Ekonomiczne Problemy Ustug, 84, pp. 395407.

Article received 17 April 2017

Accepted:

1 June 2017 